This is the version of the article accepted for publication in ICSID Review-Foreign Investment Law Journal published by Oxford University Press: https://academic.oup.com/icsidreview

Accepted version downloaded from SOAS Research Online: http://eprints.soas.ac.uk/30393

\title{
African Participation in the ICSID System: Appointment and Disqualification of Arbitrators
}

Dr Emilia Onyema

\section{Contents}

African Participation in the ICSID System: Appointment and Disqualification of Arbitrators

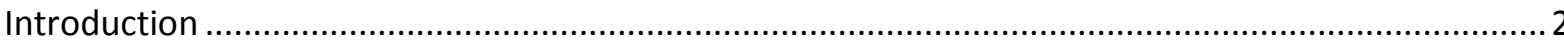

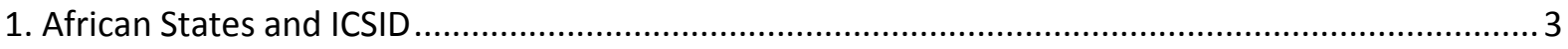

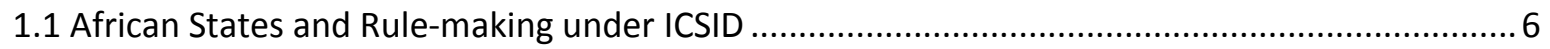

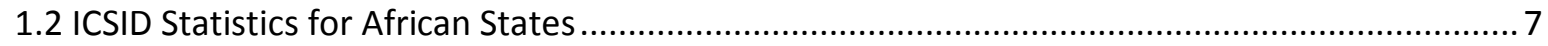

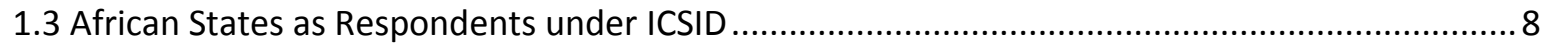

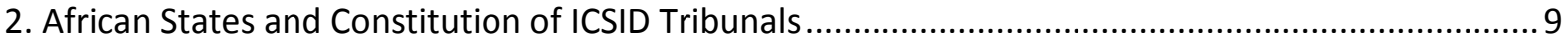

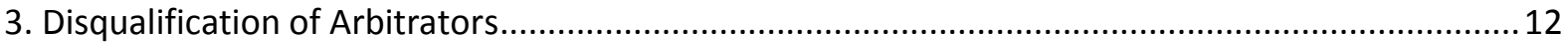

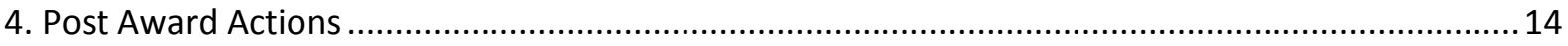

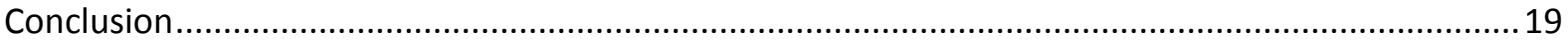

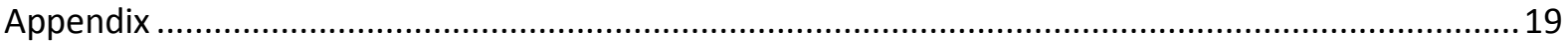

\begin{abstract}
This article critically interrogates the experience of African states within the ICSID system through an analysis of certain procedural issues. Procedural issues cover a very wide terrain of different issues during the arbitration process excepting the determination of the substantive rights and obligations of the disputants. This primary focus of this contribution is on issues related to the constitution of arbitration tribunals and applications for the disqualification of arbitrators by African States as parties to disputes under the ICSID regime. Finally it briefly mentions post award actions within the ICSID regime in which African states have also been active. It concludes that the engagement of African states within the ICSID regime will increase with the growth of cross-border intra-African investment activities. This will also lead to an increase in the participation of African lawyers in the ICSID system. This will be achieved through their appointment as counsel, arbitrators, conciliators and experts, not just by the Chairman of the ICSID Administrative Council but also by these African parties. Finally, that this increased participation of African parties and states will continue to contribute to the development of the ICSID jurisprudence and its influence on the development of international investment law.
\end{abstract}




\section{Introduction}

The editors of the second edition of Foreign Investment Disputes, defined ICSID", as, "a state-neutral international dispute resolution institution that has the primary goal of providing a forum for the resolution of foreign investment disputes". ${ }^{2}$ This definition aptly captures what ICSID is and what it does. ICSID is a centre that administers arbitration, conciliation and fact finding, under its own (Arbitration, Additional Facility, Conciliation) Rules and also under the UNCITRAL Arbitration Rules. ${ }^{3}$ Though ICSID administers conciliation proceedings, it is at its core, an arbitration centre which administers particular types of arbitration disputes. ${ }^{4}$ In this case, international investment disputes. ${ }^{5}$ Therefore purely domestic disputes between an African state and its national (legal or physical persons) will not fall within the purview of ICSID. ${ }^{6}$ However, where the legal entity is its national but controlled by foreigners, it will fall within the scope of ICSID. ${ }^{7}$ The focus of this article is investment disputes determined under the auspices of the ICSID Convention and rules in which African states and entities have been or are parties. ${ }^{8}$ It does not therefore refer to the jurisprudence or cases from other institutions that also administer investment disputes with an African state party.

We recognise that procedural issues cover a very wide range of different issues during the arbitration process excepting the determination of the substantive rights and obligations of the disputants. ${ }^{9}$ This contribution therefore primarily examines certain issues relevant to the constitution of arbitration tribunals (2) and applications for the disqualification of arbitrators (3) by African states, as parties to

\footnotetext{
${ }^{1}$ ICSID refers to the International Centre for the Settlement of Investment Disputes which was established in 1966 under the Convention on the Settlement of Investment Disputes Between States and Nationals of Other States, Washington D.C. 1965 sponsored by the World Bank. For more information on ICSID, see: https://icsid.worldbank.org/en/Pages/about/default.aspx [accessed 22 June 2018].

${ }^{2}$ R. Doak Bishop, James R. Crawford and W. Michael Reisman, Foreign Investment Disputes: Cases, Materials and Commentary, Kluwer Law International, p. 281.

${ }^{3}$ United Nations Commission on International Trade Law (UNCITRAL) Arbitration Rules 1976 (revised 2010) with text available at: https://uncitral.un.org/en/texts/arbitration/contractualtexts/arbitration [accessed 22 June 2018].

${ }^{4}$ In support of this statement is the fact that ICSID has had only 11 Conciliation cases, nine of which have an African state a party. Of the 11 Conciliation cases, only three are pending. These were filed in 2012, 2016 and 2018. The remaining eight have all been concluded.

${ }^{5}$ It is instructive that the ICSID Convention itself does not define 'investments' though various BITs usually include such definition. See for example, Article 1 (3) Nigeria-Morocco BIT signed on 3 December 2016.

${ }^{6}$ See for example, the decision on foreign ownership in National Gas S.A.E. v Egypt, ICSID Case No. ARB/11/7, where the tribunal found that the claimant companies were shell companies legitimately used as investment vehicles by an Egyptian/Canadian who effectively owned $95 \%$ of the shares. It therefore held that the claimant did not, 'satisfy the objective test in the second part of Article 25(2)(b) of the ICSID Convention; and accordingly the Tribunal decides that it has no jurisdiction over the claimant's claim in this arbitration' (para. 149 of the final award dated April 3, 2014). This decision was made under the Egypt-UAE BIT of 1997.

${ }^{7}$ As provided under Art 25(2) (b) ICSID Convention. See also the decision on Jurisdiction of October 21, 2003 in, Champion Trading Company, Ameritrade International, Inc. and Others v Egypt, ICSID Case No. ARB/02/9 decided under the USA - Egypt BIT of 1982.

${ }^{8}$ It is noted that investment disputes are also resolved under the rules of other institutions such as the ICC (International Chamber of Commerce), LCIA (London Court of International Arbitration) and PCA (Permanent Court of Arbitration). We also note that though South Africa did not make the top five host economies for FDIs in Africa in the UNCTAD World Investment Report 2018, it remains one of the major recipients (and exporter) of foreign investment in Africa. South Africa, however is not an ICSID contracting state. Over the review period of ICSID cases for this article, South Africa was respondent in one ICSID case under its Additional Facility Rule. See Piero Foresti, Laura de Carli and Others v South Africa, ICSID Case No. ARB(AF)/07/1, under the BelgiumLuxembourg - South Africa BIT of 1998.

${ }^{9}$ See for example, the scope of the recently published book by Jeffery Commission and Rahim Moloo, Procedural Issues in International Investment arbitration, Oxford University Press, 2018.
} 
disputes under the ICSID regime. It finally briefly and generally mentions post award actions within the ICSID regime as an aspect in which African states have also been active (4). A brief examination of the engagement of African states with ICSID through its published statistics (1) will be necessary to provide some context for the subsequent discussion.

\section{African States and ICSID}

ICSID is one of the institutions of the International Bank for Reconstruction and Development (the World Bank), ${ }^{10}$ and was established by the ICSID Convention of 1965 which came into force on 14 October 1966. The modern history of African states cannot be told without mentioning European colonialization. ${ }^{11}$ When the ICSID Convention opened for signature on 18 March 1965, there were only 35 independent African states and 23 of them signed the Convention before it came into force on 14 October $1966 .{ }^{12}$ This 'active' participation of African states was important in ensuring the Convention entered into force in good time. This is because the Convention required 20 signatures to come into force. ${ }^{13}$ This raises the need to interrogate why so many newly independent African states signed up to this Convention over such short period.

This question has received answers linked to the purpose of the Convention and its sponsoring agency, the World Bank. For example, Reisman notes that the purpose of the ICSID Centre and the World Bank was,

to encourage and accelerate economic development in the poorer countries [through the bank seeking to] recruit private capital by encouraging direct foreign investment in developing countries. ${ }^{14}$

Interestingly, Reisman also noted that,

The assurance of such a system it was thought, would assuage the anxieties of foreign investors and encourage them to invest, while, at the same time, cooling the enthusiasm of host governments for expropriatory initiatives. ${ }^{15}$

This is one (and popular) narrative. We must quickly note that the link between inward foreign investment and economic development of states is now widely accepted though the same cannot be said for access to investment arbitration. There is research on both sides of the debate on whether the promise of access to investment arbitration positively drives the inflow of foreign investment. ${ }^{16}$

\footnotetext{
10 The other institutions of the World Bank are: the International Development Association (IDA), the International Finance Corporation (IMF), and the Multilateral Investment Guarantee Agency (MIGA).

${ }^{11}$ Almost all African states were colonised by one or more European state though the Italians very briefly ruled Ethiopia until 1941, and Liberia was colonised by the American Colonization Society until 1847.

${ }^{12}$ See Table 2 below on the comparative dates of the independence and signing of the ICSID Convention by African states for details.

${ }^{13}$ Art. 68(2) ICSID Convention.

${ }^{14}$ W. Michael Reisman, Systems of Control in International Adjudication and Arbitration: Breakdown and Repair, Duke University Press, 1992, p.46

${ }^{15}$ Reisman, Ibid, at p.46. It appears from the current discussions on the future of international investment arbitration that the 'cooling' part of this sentence has now evolved into the unintended consequence of 'regulatory chill' complained about by governments of primarily developed states.

${ }^{16}$ See for example, Susan Franck, Empirically Evaluating Claims about Investment Treaty Arbitration, 2008; Jeswald W. Saracuse and Nicholas P. Sullivan, "Do BITs Really Work? An Evaluation of Bilateral Investment Treaties and their Grand Bargain" (2005) 46 Harvard International Law Journal, 67; Jennifer Tobin \& Susan RoseAckerman, "Foreign Direct Investment and the Business Environment in Developing Countries: The Impact of Bilateral Investment Treaties", (2003) 31 William Davidson Institute Working Paper No 587; Jason W. Yackee,
} 
Another possible explanation to the question, which in our view should not be lightly dismissed, is that as the sponsoring agency of the ICSID Convention, the World Bank needed to ensure its timely ratification. And to do this, the World Bank, to which African governments have great deference, actively encouraged as many as 23 newly independent African states to sign and ratify the ICSID Convention within such time frame. Even if it is accepted that the World Bank acted in what it perceived, at the time, to be in the best interest of these newly independent states, this belief is now open to question. The experience of African states as respondents in the ICSID (and other) system and the current backlash against Investor State Dispute Settlement (ISDS), led primarily by traditionally capital exporting states, raise this question. ${ }^{17}$ Amazu Asouzu also questioned "the appropriateness of the Convention for disputes involving African states". ${ }^{18}$

The caseload of ICSID appears to support the argument that the primary reason for setting up the ICSID system is to protect the investments of foreign investors, and not to protect the host states. We must remember that the primary drafters of the ICSID Convention were predominantly from capital exporting states. These states were also at the time, home states of the vast majority of foreign investors who are the claimants in most investment arbitration references. These states were not typically respondents and did not envisage that they themselves will become respondent states in these disputes. ${ }^{19}$ We argue that the ICSID institution is part of the system created by the Bretton Woods Institutions ${ }^{20}$ to ensure that the interests of foreign investors (who are predominantly from capital exporting and developed states) can be ventilated through a special dispute resolution mechanism and administrative centre designed for that purpose. In other words, the ICSID regime serves the purposes of capital exporting states. This assertion is not a criticism of the system but a fair summation of the economic systems of the world and its dichotomies in the 1960s when the ICSID machinery was put in place under the auspices of the World Bank. If we accept that this was one of the primary purposes of setting up the ICSID system, then surely the ICSID regime is a success. This is because ICSID has become the preferred venue for investment disputes with the highest caseload of known investment disputes of 718 cases as at December 2018. In addition, as a closed system, its

"Do Bilateral Investment Treaties Promote Foreign Direct Investment? Some Hints from Alternative Evidence", (2011) 51 Virginia Journal of International Law, 397; Maria Carkovic and Ross Levine, "Does Foreign Direct Investment Accelerate Economic Growth?" in Theodore Moran, Edward Graham and Magnus Blomstrom (eds.) Does Foreign Direct Investment Promote Development? Institute for International Economics, 2005, pp; Eric Neumayer and Laura Spess, "Do Bilateral Investment Treaties Increase Foreign Direct investment to Developing Countries?" (2005) 33 World Development, 1567; Hallward-Dreimeier M, "Do BITs attract FDI? Only a bit .. and they could bite", World Bank Policy Research Working Paper No 3121; Adeoye Akinsanya, "International Protection of Direct Foreign Investment in the Third World" (1987) 36 ICLQ 58; Susan Franck, "Foreign Direct investment, Investment Treaty Arbitration and the Rule of Law", (2007) vol 19 Pacific McGeorge Global Business Development Law Journal, p.337;

${ }^{17}$ On the backlash against ISDS and on the reform proposals, see generally, United Nations Conference on Trade and Development (UNCTAD) World Investment Report, 2013, and UNCITRAL Working Group III papers at: https://uncitral.un.org/en/working groups/3/investor-state [accessed 13 December 2018].

18 See Amazu A. Asouzu, International Commercial Arbitration and African States: Practice, Participation and Institutional Development, Cambridge University Press, 2001, pp. 215-221 on the misgivings of the sponsoring role of the World Bank.

${ }^{19}$ For example, Spain as at December 2018 had three concluded and 31 pending ICSID cases against it; while Germany had a claim of USD 1.4 Billion made against it in Vattenfall AB and Others v Germany, ICSID Case No. ARB/09/6, over a cancelled nuclear power plant construction project. The parties concluded a settlement agreement dated August 25, 2010.

${ }^{20}$ On the Bretton Woods institutions see: https://www.brettonwoodsproject.org/2005/08/art-320747/ [accessed 14 December 2018]. 
awards can only be challenged through its internal annulment process, completely shutting out review by national courts.

However, this success appears to be under threat by the same home states who in the past, enthusiastically endorsed the ISDS regime. These states are now challenging the efficacy of the international investment arbitration regime. ${ }^{21}$ It may not be too farfetched to link this distaste for investment arbitration (in its current iteration) to the fact that some of these states have had awards issued against them. ${ }^{22}$ Incidentally, African (and other developing) states can be said to now accept the regime of investment arbitration. The evidence for this acceptance is their continuing inclusion of access to international arbitration as a dispute settlement mechanism in their national investment laws and investment treaties. ${ }^{23}$

Another possible explanation for the early signing of the ICSID Convention by large numbers of African states, is the conviction of these states that they need to make themselves attractive to foreign investors. ${ }^{24} \mathrm{~A}$ message these states are continually told by various international agencies, including the World Bank. Incidentally, the majority of these investors come from the West and in most cases, from their former colonisers. ${ }^{25}$ We already mentioned above the conflicting research on this linkage and the lack of definitive research to prove that for all states, the conclusion of BITs (as an example of international investment agreement, IIA) materially affects the inflow of foreign investment. ${ }^{26}$ This assertion does not discount the relevance or contribution of foreign investment in the economic development of African states. UNCTAD consistently asserts the role foreign investment plays in global economic growth and the development of different countries. However, it is argued that because of the differences in endowment of natural resources, economic development, ease of doing business and political stability, among other factors, in African states, it may be tenuous to conclude that their signing of BITs positively impacts on the inflow of foreign investments. It may be necessary for each African state to empirically examine the connection between its BITs and inflow of investments and allow itself to be guided by the data it gathers from such research, in its activities in the BIT arena.

\footnotetext{
${ }^{21}$ See for example the position of the European Union on the current ISDS regime and its proposal for a multilateral investment court with appeal mechanism: http://ec.europa.eu/trade/policy/accessingmarkets/dispute-settlement/index en.htm [accessed 14 December 2018].

${ }^{22}$ For example, in Masdar Solar and Wind Cooperatief U.A. v Spain, ICSID Case No. ARB/14/1, one of the many disputes under the Energy Charter Treaty against Spain, damages in the principal sum of Euro 64.5 Million was made against Spain.

23 See for example the recent Pan-African Investment Code with text available at: https://au.int/en/documents/20161231/pan-african-investment-code-paic [accessed 22 June 2018]; and the Nigeria-Morocco 2016 BIT with text available at: http://investmentpolicyhub.unctad.org/IIA/treaty/3711 [accessed 22 June 2018]. Worthy of mention is that South Africa renounced some of its BITs (following the Foresti decision mentioned above at fn. 8) and adopted the Protection of Investment Act, 2015 which came into force on 13 July 2018. This new law does not include an automatic and direct access to international investment arbitration for foreign investors.

${ }^{24}$ See for example the quote by Mr Broches (then General Counsel of the World Bank) in Judge Charles N. Brower and Michael P. Daly, "A Study of Foreign Investment Law in Africa: Opportunity Awaits", in Andrea Menaker (Gen. Ed.) International Arbitration and the Rule of Law: Contribution and Conformity, ICCA Congress Series No. 19, Kluwer Law International, 2017, at p.507. The authors disapprovingly referred to Won Kidane's views (whose views we fully agree with and share) in, "The China-Africa Factor in the Contemporary ICSID Legitimacy Debate, 35 U. Penn. J. Int'I L. (2014) 559 at 585-586. See also Won L. Kidane, The Culture of International Arbitration, Oxford University Press, 2017, at p.133.

${ }^{25}$ See for example the top investor economies into Africa as noted in the UNCTAD World Investment Report, 2018. This list includes the United Kingdom and France, the predominant colonialists of African states.

${ }^{26}$ See authors listed under fn.16 above.
} 
It remains important that the story of the engagement of African states with the current international investment law (IIL) regime, which includes the ICSID system, is told correctly and objectively. This is because it will help us understand the views of African states on the current calls for the reform of the ISDS system. Charles Brower and Michael Daly have argued that African states participated in the negotiations of the ICSID Convention and the "notion that capital-exporting countries alone created investment arbitration for their own benefit" is mistaken. ${ }^{27}$ The authors did not give much weight to issues of power dynamics or the differences between participation in negotiating the ICSID Convention and the creation of the current international investment law regime (of which ICSID is a part). ${ }^{28}$

\subsection{African States and Rule-making under ICSID}

At the first ICCA Congress held in Africa in 2016, Judge Abdulqawi A. Yusuf of the International Court of Justice, in his keynote address, explored the role of arbitration in strengthening the rule of law in Africa. ${ }^{29} \mathrm{As}$ it relates to ICSID, African states have participated in the rule-making and development of ICSID processes and jurisprudence through a number of firsts: Tunisia was the first state to sign the Convention when it opened for signature; ${ }^{30}$ while Nigeria ratified the Convention first. ${ }^{31}$ The first ICSID arbitration case was, Holiday Inns v Morocco in 1972; ${ }^{32}$ and the first conciliation case was, SEDITEX $v$ Madagascar in $1982 .^{33}$ The first case where the state was the claimant against a foreign investor was, Republic of Gabon v Societe Serete ${ }^{34}$ the first arbitral award was issued in, Adriano Gardella S.p.A. $v$ Cote d'lvoire in 1977; ${ }^{35}$ and the first request for annulment of award in 1982 was in, Klockner $v$ Cameroon..$^{36}$ An African arbitrator, Ahmed Sadek El Kosheri, was President of the arbitral panel that heard the first ICSID case under an investment treaty (the 1980 BIT between the United Kingdom and Sri Lanka) and this panel also had two Africans as arbitrators. ${ }^{37}$ Through their participation in these cases, these early crop of African arbitrators contributed to the development of ICSID jurisprudence. However, the 'African voices' within the ICSID regime has since waned.

\footnotetext{
27 Judge Charles N. Brower and Michael P. Daly, "A Study of Foreign Investment Law in Africa: Opportunity Awaits", Ibid, at pp 503-510.

${ }^{28}$ It is interesting to read the very brief account in Brower and Daly's chapter in comparison to the summary as provided in Amazu Asouzu, Ibid, pp. 215-221.

${ }^{29}$ The Congress was held in Mauritius, 8-11 May 2016. See Abdulqawi A. Yusuf, "The Contribution of Arbitration to the Rule of Law - the Experience of African Countries" in Andrea Menaker (general editor) International Arbitration and the Rule of Law: Contribution and Conformity, ICCA Congress Series No. 19, Kluwer Law International, 2017, pp 27-34.

${ }^{30}$ The ICSID Convention opened for signature on 18 March 1965 and Tunisia signed it on 5 May 1965, ratified it on 22 June 1966 and it came into force in Tunisia on 14 October 1966.

${ }^{31}$ Nigeria signed the ICSID Convention on 13 July 1965 and ratified it on 23 August 1965 and it came into force in Nigeria on 14 October 1966.

32 Holiday Inns S.A. and Others v Kingdom of Morocco, ICSID Case No. ARB/72/1

${ }_{33}$ SEDITEX Engineering Beratungsgesellschaft fur die Textilindustrie m.b.h. v Madagascar, ICSID Case No. CONC/82/1

${ }^{34}$ Republic of Gabon v Societe Serete S.A., ICSID Case No. ARB/76/1

${ }^{35}$ Adriano Gardella S.p.A. v Cote d'Ivoire, ICSID Case No. ARB/74/1, award of 29 August 1977

${ }^{36}$ Klockner Industrie Anlagen $\mathrm{GmbH}$ and Others $v$ United Republic of Cameroon and Societe Camerounaise des Engrais, ICSID Case No. ARB/81/2, Decision on Annulment of 3 May 1985. Ahmed S. El Kosheri was also a member of the Ad Hoc Committee that decided the annulment. Keba Mbaye of Senegal was a member of the second annulment Ad Hoc committee.

${ }^{37}$ Asian Agricultural Products v Sri Lanka, ICSID Case No. ARB/87/3. The other members of the panel were: Samuel K.B. Asante of Ghana (who wrote a dissenting opinion) and Berthold Goldman of France.
} 


\subsection{ICSID Statistics for African States}

There are currently 162 signatory and contracting states of ICSID, 29.6\% (48) of which are African states. ${ }^{38}$ Only six African states are yet to sign the ICSID Convention. ${ }^{39}$ Statistically therefore, $87 \%$ of African states have signed and or ratified the ICSID Convention, which is a strong showing..$^{40}$ Over the 52 year history of ICSID, there has been 149 cases against African states/agencies out of the total number of 672 cases filed before ICSID as at 31 May $2018 .{ }^{41} 68.5 \%$ of the 149 cases have been concluded with $31.5 \%$ (47 cases) pending. The current top five African state respondents in ICSID cases are, Egypt with 34 cases, Democratic Republic of Congo with nine cases, Gambia with eight cases, Algeria and Republic of Guinea with seven cases each. It is noteworthy that each of these countries have recently, either experienced political instability or civil war. For example, Egypt saw a sharp rise in investment arbitration cases against it after the 'revolution' that toppled the government of Hosni Mubarak in January 2011. ${ }^{42}$

Transnational corporations of African origin have not been left out of the ICSID regime. As at 31 May 2018, 45 African (registered) corporations have instituted proceedings against states before ICSID. The vast majority of these cases (43) were against African states, ${ }^{43}$ with one case against Kuwait ${ }^{44}$ and another one case against Canada..$^{45}$ This is in contrast to the 102 cases filed against African states by non-African corporations over the same period. ${ }^{46}$ It must also be noted that the vast majority of the claimants in these cases are primarily subsidiaries of foreign owned corporations operating in the African host state of the investment. This being the case, the participation of purely African corporations in the ICSID regime remains very low. However, with the emergence and growth of major African corporations (or transnational companies) such as MTN Telecommunications ${ }^{47}$ and the Dangote Group ${ }^{48}$ this narrative may change. The reasons that will drive such change include: the fact that these African multinationals transact business across several African countries; the growth in intra-African trade in goods; the opening up of the services markets across Africa; and the projected impact of the recently signed agreement on the African Continental Free Trade Area (AfCFTA). It is anticipated that these developments will produce investment related disputes which may be resolved under the ICSID regime.

\footnotetext{
${ }^{38}$ Ethiopia (1965), Guinea Bissau (1991), and Namibia (1998) have only signed the ICSID Convention in the dates against each State.

${ }^{39}$ Angola, Djibouti, Equatorial Guinea, Eritrea, Libya, and South Africa, have not signed the Convention.

${ }^{40}$ See the status map on ICSID website at: https://icsid.worldbank.org/en/Pages/icsiddocs/List-of-MemberStates.aspx [accessed 22 June 2018]

${ }^{41}$ These are cases filed under the ICSID Convention, Arbitration or Conciliation Rules; Additional Facility Arbitration and Conciliation Rules. The number does not include cases filed under UNCITRAL or other ad hoc Rules.

42 Between 2011 and 2017, 18 cases were filed against Egypt before ICSID while between 1984 and 2009,12 cases had been filed against Egypt before ICSID.

${ }^{43}$ Cases have been brought against: Algeria, Burundi, Cote d'Ivoire, DRC, Egypt, Gabon, Gambia, Ghana, Guinea, Kenya, Liberia, Madagascar, Mali, Mauritania, Mauritius, Mozambique, Niger, Nigeria, Senegal, Sudan, Tanzania, Togo, and Zimbabwe.

${ }^{44}$ Almasryia for Operating \& Maintaining Touristic Construction Co. LLC v Kuwait, ICSID ARB/18/2

${ }^{45}$ Global Telecom Holding SAE v Canada, ICSID ARB/16/16.

${ }^{46}$ See the ICSID website for details of these cases.

${ }^{47}$ See the website of MTN Group for more information on the company at: https://www.mtn.com/en/mtngroup/about-us/Pages/default.aspx [accessed 22 June 2018]

${ }^{48}$ See the website of Dangote Group for more information on the company at: https://www.dangote.com/ [accessed 22 June 2018].
} 


\subsection{African States as Respondents under ICSID}

There is now better engagement of African states are respondents in ICSID cases. These states now actively participate in cases against them though, they are still predominantly represented by foreign law firms. This was understandable before the turn of the new millennium when knowledge about international investment law may not have been common in African law firms. However, with the notoriety of investment arbitration and the increase in publications and knowledge of investment law and arbitration, this continued side-lining of African lawyers is difficult to justify. Judge Yusuf in his ICCA 2016 keynote speech noted that:

The second issue is the lack of participation of African arbitrators in arbitral proceedings involving an African party. This also constitutes a negative factor with respect to the potential contribution of arbitration to the rule of law in Africa. The continued absence of Africans from the process raises issues of legitimacy and affects not only standard setting and knowledge transmission but also the taking of ownership of arbitration by African countries as an ADR mechanism. When the law governing arbitration involving African parties is interpreted and applied without the participation of Africans, there is both a manifest absence of African perspectives in the development of that law and a lack of potential contribution of Africans to the evolution of its rules. ${ }^{49}$

Judge Yusuf then concluded that,

There is no longer justification to continue delocalizing arbitration involving an African party be it a corporation or a State. By delocalizing the process, the ability of arbitration to contribute to the rule of law is greatly diminished..$^{50}$

We fully argue with the views of Judge Yusuf and there has been some positive movement in response. Some African states now adopt co-counselling by appointing both local and foreign counsel, ${ }^{51}$ appointing African arbitrators and in some cases, building internal capacities within the relevant government ministry or agency in charge of prosecuting investment arbitration disputes. ${ }^{52}$ This shift is the future trajectory for African states and entities. Interestingly some foreign investors suing African states already engage African law firms in addition to their foreign lawyers as counsel. ${ }^{53}$ Therefore, if the same foreign investors can trust African lawyers to represent them (albeit as cocounsel) in ICSID cases, what then will be the justification for African governments to continue to rely solely on foreign law firms to represent them, and to continue to only appoint foreign arbitrators or conciliators, in their arbitration disputes?

\footnotetext{
${ }^{49}$ Abdulqawi A. Yusuf, fn 29, at p. 31

${ }^{50} \mathrm{lbid}$, at p. 34.

${ }^{51}$ For example, in Interocean $v$ Nigeria, ICSID Case No. ARB/13/20, Nigeria is represented by both a Nigerian law firm and foreign law firm.

52 This is the situation in Kenya with internal expertise in the Office of the Attorney General; and in Egypt the Egyptian State Lawsuits Authority. In both States, these departments are staffed with lawyers with relevant expertise and training in international investment law.

${ }^{53}$ One example is in AngloGold Ashanti (Ghana) Ltd $v$ Republic of Ghana, ICSID Case No. ARB/16/15, where the Ghanaian law firm, Bentsi-Enchill, Letsa and Ankomah, Accra was appointed as co-counsel to Quinn Emanuel Urquhart \& Sullivan, London by the claimant; and the Ghana State also appointed a Ghana law firm, Kuenyehia \& Nutsukpui, Accra as co-counsel with Curtis, Mallet-Prevost, Colt \& Mosle, New York, and their Ministry of Justice. In this case, one of the arbitrators was a Zambian. This was different from the representations in the 2007 case of, Gustav F W Hamester GmbH \& Co KG v Republic of Ghana, ICSID Case No. ARB/07/24, in which both sides appointed only foreign law firms, and the Ministry of Justice as part of the Ghana team. In this case all three arbitrators were non-Africans.
} 
We also note that the continued campaign by African arbitration practitioners for inclusion in the international arbitration regime is beginning to yield some results. For example, in the AngloGold $v$ Ghana case, ${ }^{54}$ one Zambian was appointed as arbitrator by Ghana; and Nigeria appointed a British/Ghanaian as arbitrator in Interocean $v$ Nigeria. ${ }^{55}$ We predict that this inclusion of African counsel and arbitrators will increase in Africa-connected disputes.

\section{African States and Constitution of ICSID Tribunals}

Article 13(1) of the ICSID Convention empowers member states to, "designate to each Panel four persons who may but need not be its nationals". African states have nominated other African nationals and non-nationals onto these Panels. For example, Togo nominated a Nigerian onto its arbitrator panel and Sudan nominated a US/British national on its arbitrator panel. ${ }^{56}$ Parties may, but the Chairman of the ICSID Administrative Council must, choose ICSID arbitrators and conciliators from these Panels. For this reason, it is very important that African states make these designations onto the Panels. ${ }^{57}$ Such designation of duly qualified African nationals will provide greater opportunity for their selection, if not by the parties (including other states), by the Chairman of the ICSID Administrative Council when they appoint neutrals.

By virtue of this Article 13 alone, the 45 African member states of ICSID can designate 360 Africans and non-Africans ${ }^{58}$ onto ICSID Panels. As at 14 May 2018, these 45 states have collectively designated 105 individuals to both Panels. ${ }^{59}$ There is therefore a shortfall of 255 individuals that African states can designate onto ICSID Panels. These numbers do not include those Africans designated by the Chairman of the Administrative Council of ICSID ${ }^{60}$ or those that can be appointed even when not listed on any of the Panels. ${ }^{61}$ Therefore, African states can significantly increase the probability of the appointment of African arbitrators and conciliators onto ICSID Panels just by exercising this power or right to designate qualified individuals onto these Panels. As at 14 May 2018, only 19 (out of 45) African states have designated arbitrators and conciliators onto ICSID panels with unexpired tenures. ${ }^{62}$

According to the ICSID Statistics of May 2017, there is a major under-representation of African arbitrators and conciliators sitting in ICSID cases with only, "about $4 \%$ of all appointments made in ICSID cases (involving) nationals from an African State". ${ }^{63}$ The ICSID Secretariat itself recognises this anomaly and in 2017 the ICSID Secretary-General nominated four Africans onto both the arbitrator and conciliator Panels of ICSID. Some of these nominees have recently been appointed as arbitrator

\footnotetext{
${ }^{54}$ AngloGold Ashanti (Ghana) Ltd v Republic of Ghana, ICSID Case No. ARB/16/15.

${ }_{55}$ Interocean Oil Development Company \& Interocean Oil Exploration Company v Federal Republic of Nigeria, ICSID Case No. ARB/13/20. Both parties in this case also had Nigerian law firms as counsel.

${ }^{56}$ Mrs Dorothy Ufot who is a Nigerian was nominated by Togo on its Arbitrator Panel, while Sudan nominated Mr Baiju Vasani who holds USA/British citizenship, on its Panel.

${ }^{57}$ For example, Crina Baltag notes that "the designation of the arbitrators and conciliators in the Panels of the ICSID is important in the context of the Articles 30, 38, and 52 of the ICSID Convention. See Crina Baltag, "The ICSID Convention: A Successful Story - The Origins and History of the ICSID" in Crina Baltag, ICSID Convention after 50 Years: Unsettled Issues, Kluwer Law International, 2016 at p. 4.

${ }^{58}$ Some African states designated non-Africans onto these Panels. Two examples are Somalia and Seychelles.

${ }^{59}$ See Table 3 below for details of African states designations onto ICSID Panels.

${ }^{60}$ Article 13(2) of ICSID Convention empowers the Chairman of the Administrative Council of ICSID to designate ten persons (of different nationalities) to each of the Panels. In the last round of designations by the Chairman in 2017, four Africans were among those designated by the Chairman.

${ }^{61}$ In accordance with art 40 ICSID Convention. For example, Nigeria appointed Edward Torgbor, who is not listed on any of the ICSID Panels, in Interocean v Nigeria, ICSID Case No. ARB/13/20, as arbitrator.

62 See Table 3 for below the list of these states.

63 ICSID Statistics (May 2017) pp 28-29.
} 
and conciliators in ICSID cases, which is a positive development. ${ }^{64}$ These numbers suffered a dip when compared to the statistics from January to 30 June $2018 .{ }^{65}$ Over this period, 12 ICSID cases involved a sub-Saharan African state as respondent. ICSID appointed six sub-Saharan African neutrals while only one sub-Saharan African neutral was appointed by the parties. ${ }^{66}$ This data can be compared to the Middle East North Africa (MENA) region data. ${ }^{67}$ Over the same period, there were eight cases against MENA states as respondents. However, parties appointed six neutrals from the MENA region while ICSID appointed three. It is instructive that out of all the regions, it is only sub-Saharan Africa and Central America and the Caribbean regions that ICSID appointed more neutrals than the parties. ${ }^{68}$ There is a clear gap of parties not appointing (sub-Saharan) African neutrals. This in itself require interrogation to understand the reasons behind such apathy by parties. ${ }^{69}$

We therefore note that the increase in the appointment of African arbitrators and conciliators on ICSID panels is primarily driven by the ICSID Secretariat itself and not by the African states or investors appearing before ICSID panels, as parties. This presents a major difficulty because of the limited opportunities the Chairman of the ICSID Administrative Council has to appoint neutrals onto the arbitration tribunal, conciliation commission, and ad hoc committee of ICSID. ${ }^{70}$ According to the May 2017 ICSID Statistics, "in approximately 72\% of the appointments made in ICSID cases, the parties select the appointees". This leaves just above a quarter of appointments (28\%) to be made by ICSID. As compared to the January to June 2018 statistics from ICSID, parties appointed $65.4 \%$ (172) neutrals while ICSID appointed $34.6 \%$ (91) neutrals. This further confirms the observation that in the ICSID dispute resolution regime, parties make most of the appointments of neutrals.

To understand the scale of this problem, from an analysis of 101 concluded ICSID cases (arbitration and conciliation) involving African state parties between 1972 and 2015, one African was appointed as a member of the tribunal in only 18 cases and in one of those cases, there were two Africans on the same panel. In the remaining 83 cases, the three member panels were all non-Africans. ${ }^{71}$ Thus, as a question of numbers and legitimacy, African states and African parties need to seriously rethink their arbitrator/conciliator appointment strategy and practice. ${ }^{72}$

\footnotetext{
${ }^{64}$ For example, Mrs Funke Adekoya was appointed in EcoDevelopment in Europe AB \& Others $v$ Tanzania, ICSID/ARB/17/33 and Mohamed Abdel Raouf was appointed to chair the Conciliation Panel in Societe d'Energie et d'Eau du Gabon $v$ Gabon, CONC/18/1. Both appointments were made by the Chairman of the ICSID Administrative Council.

${ }^{65}$ See ICSID Caseload - Statistics (Issue 2018-2) available at:

https://icsid.worldbank.org/en/Documents/resources/ICSID\%20Web\%20Stats\%202018-2\%20(English).pdf [accessed 13 December 2018].

${ }^{66}$ Neutral is used to denote arbitrator, conciliator and annulment committee members.

${ }^{67}$ It should be noted that from this MENA region data, two cases were filed against Egypt and one case each against Algeria and Morocco. These are countries included in this article as African states.

68 ICSID Caseload - Statistics (2018-2), ibid, at p. 34

${ }^{69}$ Some reasons are: lack of expertise and lack of access or knowledge of Africans with requisite expertise and experience.

70 In relation to arbitration, the Chairman of the ICSID Administrative Council appoints arbitrators pursuant to Rule 4 of the ICSID Arbitration Rules.

${ }^{71}$ An analysis of the number of Africans appointed as arbitrator or conciliators in disputes that are not connected to Africa paints an even more dismal picture.

72 This view is strongly supported by the respondents to the SOAS Arbitration in Africa survey report who believe that one measure towards the re-balancing of the under representation of Africans in international arbitration references is for Africans to appoint their fellow (qualified) Africans as arbitrators. See Domestic and International Arbitration: Perspectives from African Arbitration Practitioners 2018 available at: http://eprints.soas.ac.uk/25741/ [accessed 22 June 2018]
} 
According to Article 37(2) (a) ICSID Convention, the parties shall agree the number of arbitrators to be appointed. In the absence of such agreement, the arbitral tribunal shall be constituted by uneven number of arbitrators. The vast majority of ICSID arbitral tribunals are composed of three members. In the 145 cases involving African states, examined for this article, all the arbitration cases were heard (or are being heard for pending cases) by three member arbitral tribunals. In only one case was a sole conciliator appointed. ${ }^{73}$ It appears from recent composition of neutrals under the ICSID Convention and Rules, that the norm is to appoint three member arbitral tribunals or conciliation commissions. This is a welcome development as it opens up the opportunity for new entrants and widening of the pool of ICSID neutrals. ${ }^{74}$

Article 37(2) (b) ICSID Convention expects each party to appointment one arbitrator. As mentioned above, parties before ICSID actively exercise their appointment rights. The nature of the disputants before ICSID panels necessitates that the majority of the appointees should not be of the same nationality as the parties. ${ }^{75}$ The practical implication of this provision is that a state may not nominate or appoint an arbitrator having its own nationality. Thus as it relates to African states (or African investors), they can appoint qualified arbitrators from other African states.

From a brief research conducted on ICSID Africa related cases for this article, there appears to be a connection between the counsel representing the parties and the nationality of arbitrators appointed by the parties. For example, where an international or foreign law firm is appointed as sole counsel by an African party, there is greater likelihood that the appointed arbitrator will be non-African. ${ }^{76}$ In those cases where an African state appointed an African as arbitrator on the panel, the counsel or one of them was African. ${ }^{77}$ This is an important finding because African lawyers will know other Africans with requisite knowledge and expertise that can be appointed as arbitrator (or conciliator) onto ICSID panels.

In addition, the role of some of the law firms that advise state parties in these disputes cannot be under-rated. The average investment arbitration counsel believes very strongly in their clients exercising their right to appoint an arbitrator onto the panel. The cliché that 'an arbitration is as good as the arbitrators ${ }^{\prime 78}$ is more than a cliché for most investment arbitration lawyers. Some counsel believe that whether a party will win or lose a reference, can be predicted just by knowing the individuals that make up the arbitral tribunal. ${ }^{79}$ This belief has led to the labelling of some arbitrators

\footnotetext{
73 One Mexican conciliated the dispute, Equatorial Guinea v CMS Energy, ICSID Case No. CONC(AF)/12/2.

${ }^{74}$ See for example the raft of first time appointments in recently constituted ICSID arbitral tribunals and conciliation commissions.

${ }^{75}$ Art. 39 ICSID Convention. This nationality requirement informed Rule 3 of the ICSID Arbitration Rules. See also Christoph Schreuer, The ICSID Convention: a Commentary, Cambridge University Press, 2001, pp. 498-506. At p. 500 Prof Schreuer notes that there are 'good practical reasons for excluding or restricting the appointment of national arbitrators'.

${ }^{76}$ See fn 53 above.

77 See for example Interocean $v$ Nigeria, above at fn 61.

${ }^{78}$ See for a chapter dedicated to this maxim, Lord Hacking, "Arbitration is only as Good as its Arbitrators", in S. Kröll, L.A. Mistelis, P. Perales Viscasillas \& V. Rogers (eds), Liber Amicorum Eric Bergsten. International Arbitration and International Commercial Law: Synergy, Convergence and Evolution, Kluwer Law International, 2011, 223-230

${ }^{79}$ See for example Michael Waibel and Yanhui Wu, "Are Arbitrators Political? Evidence from International Investment Arbitration", available online at: http://www-bcf.usc.edu/ yanhuiwu/arbitrator.pdf [accessed 22 June 2018] for research-based mapping of arbitrator background to outcome of investment disputes. See also for a critique of the behavioural methodology, Stavros Brekoulakis, "Systemic Bias and the Institution of International Arbitration: A New Approach to Arbitral Decision-Making" (2013) Journal of International Dispute Resolution, Vol. 4 No. 3, p. 553.
} 
as investor-friendly or state-friendly. ${ }^{80}$ Such labelling is supported by cases where particular individuals appear to only be appointed by investors or by states. ${ }^{81}$ However, we also note that there is a third category of arbitrators who can neither be pigeonholed into the investor-friendly or statefriendly dichotomy.

We note that African state parties have not always actively participated in the composition of the arbitral panels. According to data mined from the ICSID website, in 119 cases, African states, as respondents, appointed one member of the arbitral panel. In 51 cases, African states, as respondents, did not make this appointment which was then made for them by the Chairman of the ICSID Administrative Council. ${ }^{82}$ This behaviour has now changed. Possible explanations for this change include the greater awareness and public interest generated in the subject matter of investment arbitration generally and ICSID disputes more particularly. The Biwater $v$ Tanzania dispute is an example of the public nature of ICSID cases which affect the daily lives of citizens of state respondents. The dispute in Biwater arose from the operation and management of the water system in Dar es Salaam..$^{83}$

Another reason for the behavioural change may be the increase in knowledge of the law and practice of investment arbitration. This is through recent publications and access to academic and practitionerbased textbooks, commentaries and blogs on investment arbitration, which are publicly available. ${ }^{84}$ These publications evidence the increase in knowledge and awareness of issues relevant to investment law and arbitration. Finally, the reportage of investment disputes and outcomes in the popular media also creates awareness. ${ }^{85}$ All of these publicity mean there is hardly any hiding place for irresponsible behaviour on the part of African respondent states, such as not engaging in the dispute resolution process or not appointing arbitrators onto panels. Such public scrutiny may have both positive and negative impacts. For example, the engagement of state parties is a positive impact while sensational and inaccurate reportage on investment disputes have a negative impact.

Thus one positive outcome from the publicity of investment disputes, is better engagement in the process by African state parties. Such engagement has led to the appointment of some African lawyers as counsel (or co-counsel) and appointment of some African arbitrators. This positive trajectory can only grow in the future.

\section{Disqualification of Arbitrators}

Another procedural issue where African states have been active is in applying for the disqualification of arbitrators. According to Article 57 of the ICSID Convention, a party may propose the disqualification of any member of the arbitral tribunal for "a manifest lack of the qualities" required of an ICSID arbitrator, or that the arbitrator "was ineligible for appointment to the Tribunal" as required under

\footnotetext{
${ }^{80}$ For an overview of some of the debates, this Cecilia Olivet and Pia Eberhardt, "Arbitrators' Role in the Recent Investment Arbitration Boom", first published in Investment Treaty News (ITN) Issue 3 Vol. 3 and available online at: https://www.tni.org/es/node/12279 [accessed 22 June 2018]

${ }^{81}$ We also note that such labels appear not to take account of the strengths and weaknesses, applicable laws and merits of the case of the parties.

${ }^{82}$ This data was mined from the ICSID Cases database on the ICSID website.

${ }^{83}$ Biwater Gauff (Tanzania) Ltd v United Republic of Tanzania, ICSID Case No. ARB/05/22

${ }^{84}$ The vast majority of these publications can be purchasing via online bookstores such as amazon.com and delivered in most cities of the world.

${ }^{85}$ This is so even though most of such reporting may be skewed and not objectively reflect the dispute and its outcome.
} 
the Convention. ${ }^{86}$ The non-challenged members of the tribunal will determine the disqualification proposal under Article 58 of the Convention. ${ }^{87}$ The vast majority of arbitrator challenges under ICSID are denied and most of the applications are decided by the Chairman of the Administrative Council and remain unpublished. ${ }^{88}$ For example, the Chairman decided and rejected the disqualification application of Gabon in its arbitration with Participaciones Inversiones Portuarias. ${ }^{89}$ Again, the Chairman decided and rejected the arbitrator disqualification in Getma v Guinea.$^{90}$ In both cases, the two unchallenged arbitrators could not agree on the disqualification applications. According to Commission and Moloo, "Of the ninety-three disqualification proposals that resulted in a decision, five proposals were upheld (5\%), and eighty-eight were declined (95\%). ${ }^{91}$ In some ICSID cases, the whole panel of arbitrators (including the arbitrator appointed by the state) have been challenged. One example is the BSG and Others $v$ Guinea dispute and recently in Interocean $v$ Nigeria. ${ }^{92}$

One very common ground for the challenge of arbitrators is an allegation of "manifest lack of independence and impartiality" on the part of the challenged arbitrator. In 13 cases against African states, either the claimant or the state party challenged at least one member of the tribunal. ${ }^{93}$ None

\footnotetext{
${ }^{86}$ In accordance with Art 14 ICSID Convention. Also relevant to this issue are, Rule 6 (on the declaration of independence and deemed resignation of an arbitrator), and Rule 9 (on the procedure for the disqualification of arbitrators) ICSID Arbitration Rules.

${ }^{87}$ It is noted that the first published ICSID Panel to uphold the disqualification proposal of one of its members was in Curatube International Oil Company LLP \& Devincci Salah Hourani v Kazkhstan, ICSID Case No. ARB/13/13, Decision on the proposal for Disqualification of Bruno Boesch (March 20, 2014)

${ }^{88}$ See for example, Meg Kinnear and Frauke Nitschke, "Disqualification of Arbitrators under the ICSID Convention and Rules, Challenges and Recusal of Judges and Arbitrators" in Chiara Giorgetti (ed.), International Courts and Tribunals, Brill/Nijhoff, 2015, pp 247-292, for discussion on grounds and decisions on ICSID arbitrator challenges; Baiju S. Vasani \& Shaun A. Palmer, "Challenge and Disqualification of Arbitrators at ICSID: a New Dawn", (2015) Vol 30 Issue 1, ICSID Review - Foreign Investment Law Journal, 194; and Maria Nicole Cleis, The Independence and Impartiality of ICSID Arbitrators: Current Case Law, Alternative Approaches and Improvement Suggestions, Brill, 2017

89 Participaciones Inversiones Portuarias SARL v Gabon, ICSID Case No. ARB/08/17, Decision on proposal for Disqualification of an Arbitrator (November 12, 2009).

90 Getma International \& Others $v$ Guinea, ICSID Case No. ARB/11/29, Decision on the proposal for the Disqualification of Arbitrator, Bernardo M. Cremades (June 8, 2012) - this challenge was dismissed.

91 Jeffery Commission and Rahim Moloo, Procedural Issues in International Investment Arbitration, Oxford University Press, 2018, pp 50-64 at p.53

92 BSG Resources Ltd, BSG Resources (Guinea) Ltd and BSG Resources (Guinea) SARL v Republic of Guinea, ICSID Case No. ARB/14/22 where Kauffman-Kohler, van den Berg and Mayer were all challenged by the claimants. The challenges were refused. Interocean Oil Development Company and Another v Nigeria, ICSID Case No. ARB/13/20, decision on the proposal to disqualify all members of the Tribunal available at: http://icsidfiles.worldbank.org/icsid/ICSIDBLOBS/OnlineAwards/C3043/DS11476 En.pdf [accessed 14
} December 2018].

${ }^{93}$ These cases are: CDC v Seychelles, ICSID Case No. ARB/02/14 where the challenge application was rejected for being untimely; Standard Chartered Bank (Hong Kong) Ltd v Tanzania, ICSID Case No. ARB/15/41 where the challenged arbitrator resigned; Utsch M.O.V.E.R.S. International \& Others v Egypt, ICSID Case No. ARB/13/37, where the decision on the challenged arbitrator is still pending though the case has been discontinued; $R S M$ Production Corporation $v$ Central Africa Republic, ICSID Case No. ARB/07/2, where the challenged arbitrator resigned; Tanzania Electric Supply Co Ltd v Independent Power Tanzania Ltd, ICSID Case No. ARB/98/8, where claimant challenged two arbitrators, one resigned and decision on the other arbitrator is still pending though the case has been discontinued; Champion Holding v Egypt, ICSID Case No. ARB/16/2, where one arbitrator was challenged and the challenge was unsuccessful; BSG v Guinea, ICSID Case No. ARB/ 14/22, where all three arbitrators were challenged and the challenge was unsuccessful; Getma v Guinea, ICSID Case No. ARB/11/29, where one arbitrator was challenged and the challenge was unsuccessful; Carnegie Minerals v Gambia, ICSID Case No. ARB/09/19, where one arbitrator was challenged and the challenge was unsuccessful; PIP v Gabon, ICSID Case No. ARB/08/17, where one arbitrator was challenged and the challenge was unsuccessful; African 
of these arbitrator disqualification applications was upheld. The key question is why, in the face of such failures, do African states challenge ICSID arbitrators and what can be done to reduce the incidences of such arbitrator challenges? With reference back to Judge Yusuf's ICCA 2016 keynote speech, it is probable that the diversity of ICSID panels will reduce the anxiety of African state parties which leads them to challenge some of the arbitrators on their panels. ${ }^{94}$

Bias is a matter of perception and interpretation by the parties of an arbitrator's overt and unconscious gestures and choice of words and even glances during the arbitration. Won Kidane refers to this as 'cultural miscommunication' ${ }^{95}$ It is how the relevant party interprets these gestures that will determine whether or not they pursue a disqualification application. For example, where an arbitrator does not understand the witnesses of one party (probably because of language differences) or the arbitrator betrays a preconception or perception of prejudice against that state or its officials (for example, the widely held perception that officials of some African states are corrupt), the state party will suspect bias. Such suspicion leads to lack of confidence in the ability of the member or members of the tribunal to exercise independent and objective judgement in their interpretation of the facts and evidence presented before them. Surely, diversity of the arbitrators on the panels, will bolster confidence in the tribunal. It will also help to foster a sense of inclusion in the arbitral process. Confidence of the parties in the tribunal may lead to a reduction in the number of applications for the disqualification of arbitrators on ICSID tribunals.

There is generally, increasing number of challenges to ICSID arbitrators and it appears that this trend will continue. ${ }^{96}$ The many arbitrator challenge applications and decisions, have made the grounds for upholding such challenges clearer, which in itself will provide better guidance to parties seeking to apply to disqualify an arbitrator. ${ }^{97}$ It is however, doubtful that this clarity will dissuade parties from challenging ICSID arbitrators. There is nothing wrong per se with applying for the disqualification of ICSID arbitrators (which is why it is provided for in the Convention). What should not be encouraged, is frivolous applications for the disqualification of arbitrators, most of which are made as a form of delay tactics. Finally, applications for the disqualification of arbitrators should not evolve into a 'necessary step' in ICSID arbitration references, in the same manner as jurisdictional challenges have now evolved. ${ }^{98}$

\section{Post Award Actions}

This section briefly discusses the actions parties can take after the issuance of the final award because African states have also been active in this field. Parties before ICSID arbitration panels can always

Holding Co. of America v Democratic Republic of Congo, ICSID Case No. ARB/05/21, where one arbitrator was challenged and the challenge was unsuccessful; World Duty Free v Kenya, ICSID Case No. ARB/00/7, where the challenge to one arbitrator was rejected on technical grounds by the other two arbitrators; and Interocean $v$ Nigeria, ICSID Case No. ARB/13/20, where Nigeria challenged the three arbitrators and the challenge was unsuccessful.

94 Abdulqawi Yusuf, fn 29 at p.31

95 See Won L. Kidane, The Culture of International Arbitration, Oxford University Press, 2017 at pp.10 - 15 for various examples.

${ }^{96}$ See for a detailed engagement with the issues raised by arbitrator disqualification under ICSID, Maria Nicole Cleis, The Independence and Impartiality of ICSID Arbitrators: Current Case Law, Alternative Approaches and Improvement Suggestions, Brill, 2017 particularly, chapter 2 titled, "Disqualification Decisions under the ICSID Convention and Arbitration Rules, pp 31-87.

${ }^{97}$ For details of the clarity, see for example, Vasani \& Palmer, fn 88, at pp. 207-221.

98 It has almost become the norm for the respondent in an ICSID reference to challenge the jurisdiction of the tribunal, even where such application lacks legal basis. 
agree to settle their dispute before the award is issued. ${ }^{99}$ When this is done, the tribunal will notify the Secretariat of the discontinuance of the reference in accordance with Rule 43(1) of the ICSID Arbitration Rules. ${ }^{100}$ The parties may also request the tribunal to embody their terms of settlement in an award as was done in Millicom $v$ Senegal. ${ }^{101}$ In the absence of settlement and with the active pursuit of the proceedings by the parties, ${ }^{102}$ the tribunal will make an award after the close of the hearing. The award can be made by a unanimous or majority decision and is required to be made in writing, signed and any dissenting opinion (or statement) may be attached to the award. ${ }^{103}$ Authenticated original copies of the award will then be despatched to the parties by the ICSID Centre. ${ }^{104}$

Following the despatch of the final award of the arbitral tribunal, the parties can take several actions, one of which is to seek the annulment of the award. ${ }^{105}$ The other actions the parties can take are: to request additional award including rectification of clerical, arithmetical or similar error in the award; ${ }^{106}$ interpretation of the award; ${ }^{107}$ and revision of the award. ${ }^{108}$ During the pendency of any of these requests, the enforcement of the award may either be automatically stayed (in accordance with the proviso to the various provisions in the Convention) or on a request by a party for such stay. ${ }^{109}$

As a closed system, the parties to ICSID proceedings do not have access to national courts to challenge the resulting award. One reason for this is to prevent the state party from getting an advantage over the investor by unduly influencing its courts to annul or refuse to enforce the award. Granting states such advantage would have made the ICSID regime less attractive to most developed states, whose citizens, at the time of the conclusion of the ICSID Convention, formed the vast majority of foreign investors.

The right of the judgment debtor (or loser) to seek annulment of an award is balanced by the right of the judgment creditor (or winner) to seek the enforcement of the award. The grounds on which an

\footnotetext{
99 In accordance with Rule 43 of ICSID Arbitration Rules.

100 Data from the ICSID Cases Search Engine shows that the vast majority of concluded cases involving African States were discontinued. In some of these cases, the parties reached a settlement. One example is APCL Gambia B.V. v Republic of The Gambia, ICSID Case No. ARB/17/40

101 Millicom International Operations B.V. and Sentel GSM S.A. v Senegal, ICSID Case No. ARB/08/20, in accordance with Rule 43(2) ICSID Arbitration Rules.

102 This refers to the parties taking steps in the proceedings when required since if they do not, they may be deemed to have discontinued the proceedings in accordance with art. 44 ICSID Arbitration Rules.

${ }^{103}$ See for details on the award, Rule 47 ICSID Arbitration Rules.

104 The original copies of the award shall be authenticated by the Secretary General of ICSID in accordance with Rule 48 of the ICSID Arbitration Rules.

105 Art 52 ICSID Convention

${ }^{106}$ Art 49(2) ICSID Convention

107 In accordance with art 50 ICSID Convention, the parties can request an interpretation of the award, for example, as was done in, Wena Hotels Ltd v Egypt, ICSID Case No. ARB/98/4, where the application was allowed in part.

${ }^{108}$ Art 51(1) ICSID Convention. One Africa-connected case requested for revision of the award: In American Manufacturing \& Trading Inc. v Democratic Republic of Congo, ICSID Case No. ARB/93/1, the award on the merit was rendered on 21 February 1997 and the revision proceeding commenced in 1999, following which the parties settled and the matter was discontinued.

${ }^{109}$ See for example, CDC Group v Seychelles, ICSID Case No. ARB/02/14, decision of 14 July 2004. See also case note: Dietmar W. Prager, "CDC Group PLC v Republic of the Seychelles, Decision on Whether or not to Continue Stay and Order, ICSID Case No. ARB/02/14, 14 July 2004", A contribution by the ITA Board of Reporters, Kluwer Law International, originally published at: http://www.transnational-dispute-management.com [accessed 22 June 2018].
} 
ICSID award may be annulled are very limited. ${ }^{110}$ On the procedure for seeking annulment of an ICSID award, the applicant files a request for annulment with the Secretary-General of ICSID within 120 days after the date the award was rendered (or discovery of the corruption, if that is the ground for the annulment application). ${ }^{111}$ The request for annulment will be decided by an Ad Hoc Committee composed of three individuals. African arbitrators have fared better as members of the Ad Hoc Committees in comparison to ICSID arbitral tribunals. ICSID currently has a total of 117 annulment cases (79 concluded and 38 pending). 38 Africans have sat (or are sitting) on these Ad Hoc Committees. This represents $10.8 \%$ of all appointments on to Ad Hoc Committees compared to $4 \%$ of Africans on ICSID arbitral panels in 2017. ${ }^{112}$

As is evident, and confirmed by the 2018 Queen Mary International Arbitration survey for example, the primary attractiveness of arbitration is the enforceability of the arbitral award. ${ }^{113}$ To assure the enforcement of ICSID awards, its member states accepted that:

Each Contracting State shall recognize an award rendered pursuant to this Convention as binding and enforce the pecuniary obligation imposed by that award within its territories as if it were a final judgement of a court in that State. ${ }^{114}$

As mentioned above, the modern international investment law regime is designed to protect and safeguard the property of the foreign investor from certain actions of (primarily host) states. Such safeguard therefore, requires an effective enforcement mechanism for ICSID awards. It is this mechanism that gives 'teeth' to the ICSID system.

Each ICSID member state designates and notifies the Centre, the court or other authority that will enforce ICSID awards within its jurisdiction, pursuant to Article 54(2) of the Convention. As at 30 May 2018, of the 45 African states that have ratified the Convention, 15 have not notified the Centre of the particular court or authority that will determine enforcement applications for ICSID awards. ${ }^{115}$ This represents one third of the current African states that have ratified the ICSID Convention. Such designation is designed to make the recognition and enforcement of ICSID awards seamless. This also adds to the attractiveness of the recourse to the Convention. It is therefore important that these African states make the necessary designation and notify ICSID. It is not practicable to presume that a particular court will have such jurisdiction because practice across the continent differs. For example, in some African states, jurisdiction reposes in the High Court; ${ }^{116}$ in others it reposes in the Supreme

\footnotetext{
${ }^{110}$ Article 52(1) ICSID Convention lists the grounds as: "(a) that the Tribunal was not properly constituted; (b) that the Tribunal has manifestly exceeded its powers; (c) that there was corruption on the part of a member of the Tribunal; (d) that there has been a serious departure from a fundamental rule of procedure; or that the award has failed to state the reasons on which it is based".

${ }^{111}$ Art 52 ICSID Convention. The request must, in any event, be made "within three years after the date on which the award was rendered", according to art 52(2).

112 This data was harvested from: https://icsid.worldbank.org/en/Pages/cases/AdvancedSearch.aspx [accessed 22 June 2018].

${ }^{113}$ Queen Mary/White \& Case 2018 International Arbitration Survey: The Evolution of International Arbitration found that enforceability of awards is the most valuable characteristic of arbitration for $64 \%$ of their respondents. The survey report is available online at: http://www.arbitration.qmul.ac.uk/research/2018/ [accessed 22 June 2018].

${ }^{114}$ Art 54 ICSID Convention.

${ }^{115}$ See Table 3 below for a full list of African states and their designated courts/authorities and those states that have not notified any designation.

${ }^{116}$ For example, Central Africa Republic, Ghana, Kenya, Malawi, Morocco, Niger, Swaziland, Togo, Tunisia, Zambia, and Zimbabwe.
} 
Court. ${ }^{117}$ In other states the jurisdiction lies with a non-judicial authority. ${ }^{118}$ In other states it lies with the court of Appeal; ${ }^{119}$ and yet for other states, in a particular court in an identified city. ${ }^{120}$

A party seeking the recognition and enforcement of an ICSID award need to furnish to the designated authority a "copy of the award certified by the Secretary-General". ${ }^{121}$ The execution of such award will be in accordance with the normal internal processes of the enforcing state. ${ }^{122}$ This is not unique to ICSID, as Oppong and Niro note that,

Although most international judgements are likely to be against sovereign states, all the international court treaties are silent on the issue of state immunity from jurisdiction and enforcement actions at the national level. ${ }^{123}$

ICSID member states effectively waive their immunity from jurisdiction by consenting to arbitration or conciliation under the ICSID regime. ${ }^{124}$ However, such consent or waiver does not extend to cashing in the award. It is noted that during the drafting of the Convention, "there was a general expectation that compliance by the host state with ICSID awards would not be a practical problem and that voluntary compliance would be a natural consequence of the treaty obligation expressed in Art. 53."125 Thus, the ICSID Convention preserves the right to immunity from execution of its member states. ${ }^{126}$ On this basis, a state judgment-debtor may still resist the execution of an enforced ICSID award. It is important to recollect that where a state judgment-debtor refuses or fails to abide by or comply with the award, the home state of the investor can "give diplomatic protection or bring an international claim" in favour of its citizen. ${ }^{127}$

It is generally asserted that most state judgment debtors under ICSID comply with the award made against them. Some of the reasons for such voluntary compliance include, reputational damage, pressure from the World Bank, and political and diplomatic pressure to pay up (recognised as a valid tactic under Article 27(2) ICSID Convention). In relation to the benefits of the privacy of arbitration, where a state judgment debtor pays the arbitral award, the fact of the existence of the arbitration and its outcome may be known, but the details of the award may not be public. In contrast, immediately the execution of an ICSID award goes before a court, the details of such award become public.

\footnotetext{
${ }^{117}$ For example, Benin, Burkina Faso, Cameroon, Liberia, Madagascar, Mauritania, Mauritius, and Nigeria.

${ }^{118}$ For example, Botswana, Egypt, Guinea, Lesotho, and Sierra Leone.

${ }^{119}$ For example, Senegal.

${ }^{120}$ For example, Burundi, Congo, Cote d'Ivoire, Rwanda, and Sudan.

${ }^{121}$ Art. 54(2) ICSID Convention. The exercise of national courts is limited to confirming the authenticity of the award as noted by Albert Jan van der Berg, "Some Recent Problems in the Practice of Enforcement under the New York and ICSID Conventions, ICSID Review - Foreign Investment Law Journal, Vol 2, No. 2 (1987) p.439 at p.448.

${ }^{122}$ Art 54(3) ICSID Convention.

${ }^{123}$ Richard Frimpong Oppong and Lisa C. Niro, "Enforcing Judgments of International Courts in National Courts", Journal of International Dispute Settlement, 2014 Vol 5 p. 344 at p.352

124 In accordance with arts 25 and 26 ICSID Convention; various BITS or MITS which contain a reference to arbitration for resolution of disputes or in national investment laws. According to the May 2017 ICSID Statistics Special Focus on Africa, the basis for invoking ICSID jurisdiction was BIT (26\%); investment law of the host State (26\%) and investment contract between the host State and the investor (46\%) of cases.

${ }^{125}$ Christoph Schreuer, ICSID Commentary, Ibid, at p.1107.

${ }^{126}$ Art 55 ICSID Convention.

${ }^{127}$ In accordance with Art 27 ICSID Convention. There is no known case involving an African state where the home state of the foreign investor resorted to diplomatic protection on this ground. See also Christoph Schreuer, "Investment Protection and International Relations" in A. Reinisch \& U. Kriebaum (eds.), The Law of International Relations - Liber Amicorum Haspeter Neuhold, Eleven International Publishing, 2007, p. 345
} 
The law of sovereign immunity against execution is still generally governed by customary international law though some states have codified their rules on the issue. ${ }^{128}$ One example of an African state with its sovereign immunity law codified is South Africa. ${ }^{129}$ The key issue for the triumphant investor at this stage is finding state property against which execution for the award debt can be levied. It is accepted that execution cannot be enforced against state assets of a public nature or that are used for public purposes, for example, the embassy account of the state or its Central Bank account. ${ }^{130}$ However, in most jurisdictions, execution can be levied against commercial assets or assets used for commercial purposes by a state. ${ }^{131}$ There are two hurdles. The first is the definition of commercial assets or assets used for commercial purposes, and the second and more complicated issue is execution against assets that have a mixed purpose (both commercial and public use).

Some commentators have argued that implicit in a state's consent to ICSID arbitration, is also their consent to abide by (so, perform) the award. ${ }^{132}$ It does not appear that those states that raise sovereign immunity arguments at the execution stage of the award agree with this argument. Emmanuel Gaillard makes the argument for the agencies that states use for commercial activities to be stripped of immunity while maintaining immunity for public purpose. This, in his view, will ensure the availability of greater assets against which judgement creditors can execute and realise the benefits of the arbitral award. ${ }^{133}$ In our view, if private entities are not restricted in how they organise (and the vehicles they use to achieve this) their economic affairs, it may not be convincing to argue that states should be so constrained. It is important to keep in view that an award that has been enforced is a debt owed by the debtor. All that immunity constrains is the immediate execution of that award. The lack of, or delay in execution does not deprive the award of that value of being a debt owed (within applicable limitation laws). It is becoming obvious with the imposition of stiff interest rates, that there is a penalty against judgement debtors who delay payment. In our view, it is such stiff penalties that will 'force' recalcitrant judgement debtors (including states) to pay up.

It can safely be concluded that a state judgement debtor that does not wish to pay the award, will fight every effort by the judgement creditor to realise the award. States may have different reasons for pursuing such course of action. However in our view, if the dispute was fairly fought and the state lost, then the state (as a responsble and rule-abiding citizen) ought to pay up without further delay. In

\footnotetext{
${ }^{128}$ Notable examples are the United States Foreign Sovereign Immunities Act 1976, and the United Kingdom State Immunity Act 1978.

129 See the South Africa Foreign States Immunities Act 1981 amended 1985 available at: http://www2.saflii.org/za/legis/hist act/fsia87o1981307/fsia87o1981a20n1981430.html [accessed 22 June 2018].

${ }^{130}$ See for example the recent decision of the English courts in, $L R$ Avionics $v$ Federal Republic of Nigeria

[2016] EWHC 1761 (Comm) on property used for commercial purposes and sovereign immunity.

${ }^{131}$ The Draft United Nations Convention on Jurisdictional Immunities of States and Their Property, 2004, though not yet in force, recognises the commercial exception to sovereign immunity against enforcement under its art.10. This draft Convention has been signed by five African States (Equatorial Guinea, Madagascar, Morocco, Senegal and Sierra Leone) and is available at:

https://treaties.un.org/Pages/ViewDetails.aspx?src=IND\&mtdsg no=III-13\&chapter=3\&lang=en [accessed 22 June 2018].

132 See for example, Georges R. Delaume, "Sovereign Immunity and Transnational Arbitration" in Julian D. M. Lew, Contemporary Problems in International Arbitration, Springer, 1987, at pp 313-316; Emmanuel Gaillard, "Effectiveness of Arbitral Awards, State Immunity from execution and Autonomy of State Entities: Three Incompatible Principles" in Emmanuel Gaillard \& Jennifer Younan (eds.) State Entities in International Arbitration, Juris Publishing, 2008, pp. 179-181.

${ }^{133}$ Emmanuel Gaillard, "Effectiveness of Arbitral Awards, State Immunity from Execution and Autonomy of State Entities: Three Incompatible Principles" in Emmanuel Gaillard \& Jennifer Younan (eds.), State Entities in International Arbitration, Juris Publishing, 2008 at 188-193.
} 
support of this view is the comment by the ad hoc Committee (for annulment of the award) in MINE $v$ Guinea, that state immunity is not an "excuse for failing to comply with an award". ${ }^{134}$ Antonio Parra, former Deputy Secretary General of ICSID had noted that the vast majority of ICSID awards against states are complied with voluntarily by such states, though in some cases, execution had been resisted on the ground of sovereign immunity. ${ }^{135}$ In this context, Antonio Parra discussed four such cases, three of which involved African states as the resisting party. ${ }^{136}$

\section{Conclusion}

As recognised by Amazu Asouzu in 2001, "African States have no doctrinaire opposition to arbitration per se and would be willing to contribute to its development provided their interests are and will be recognised and protected". ${ }^{137}$ This position has not changed. Our brief analysis in this contribution show that the engagement of African states in ICSID cases has increased year on year, with states as respondents but also African businesses as investors and claimants. It is envisaged that this engagement will increase as cross-border intra-African investment activities grow. This will be particularly relevant when the investment chapter of the African Continental Free Trade Area Agreement comes into force. This increase is currently driven by the growth in size, activities and number of private African investment entities and transnational corporations. Such participation of African parties and states will continue to contribute to the development of the jurisprudence of ICSID and its influence on the development of international investment law. Following on from this increase in African participation, it is predicted that there will be an increase in the recourse of African parties to African lawyers and the appointment of African arbitrators and conciliators, not just by the Chairman of the ICSID Administrative Council but also by African parties. This engagement of Africans as disputing parties, counsel, arbitrators, conciliators, experts and fact finders within the ICSID system will enrich ICSID jurisprudence.

\section{Appendix}

Table 1: Designations to ICSID Panels by African States as at 14 May 2018

\begin{tabular}{|l|l|l|l|l|}
\hline No & African State & Arbitrator Panel & Conciliator Panel & Comments \\
\hline 1 & Algeria & 4 & 3 & - \\
\hline 2 & Angola* & - & - & - \\
\hline 3 & Benin Republic & 3 & 2 & - \\
\hline 4 & Botswana & 4 & 4 & $\begin{array}{l}\text { The same individuals on both } \\
\text { Panels and all expired in 2010. }\end{array}$ \\
\hline 5 & & & & All expired in 2010. \\
\hline 6 & Burkina Faso & 4 & 4 & All expired in 2016. \\
\hline 7 & Cabo Verde & 4 & 0 & Need to make appointments. \\
\hline 8 & Cameroon & 4 & 0 & - \\
\hline
\end{tabular}

\footnotetext{
${ }^{134}$ Maritime International Nominees Establishment v Guinea, ICSID Case No. ARB/84/4, Interim Order No.1 Concerning Guinea's Application for Stay of Enforcement of the Award dated august 12, 1988.

${ }^{135}$ Antonio R. Parra, "Enforcement of ICSID Arbitral Awards" paper delivered at the $24^{\text {th }}$ Joint Colloquium on International Arbitration, Paris, November 16, 2007, at pp 10-11. Copy of paper is available on the ICCA website. ${ }^{136}$ The cases are: S.A.R.L. Benvenuti \& Bonfant $v$ Congo, 65 ILR 91 (1984), 1 ICSID Rep. 368 (1993). The second case was the Liberia Eastern Timber Corporation v Liberia, 26 ILM 695 (1987). The third case was, Société Ouest Africaine des Bétons Industriels v Senegal, 29 ILM 1341 (1990) and decision of the French cour de Cassation in 30 ILM 1169 (1991).

${ }^{137}$ Amazu Asouzu, Ibid, at p. 228.
} 


\begin{tabular}{|c|c|c|c|c|}
\hline 9 & $\begin{array}{ll}\text { Central } & \text { Africa } \\
\text { Republic } & \end{array}$ & 2 & 4 & All expired in 1986. \\
\hline 10 & Chad & 4 & 0 & All expired in 2010. \\
\hline 11 & Comoros & 4 & 4 & $\begin{array}{l}\text { The same individuals on both } \\
\text { Panels and all expired in } 1987 \text {. }\end{array}$ \\
\hline 12 & Congo Republic & 0 & 0 & Need to make appointments. \\
\hline 13 & $\begin{array}{l}\text { Democratic } \\
\text { Republic of Congo }\end{array}$ & 4 & 4 & $\begin{array}{l}\text { Two individuals in both Panels; one } \\
\text { expired in March } 2018 .\end{array}$ \\
\hline 14 & Cote d'Ivoire & 0 & 0 & Need to make appointments. \\
\hline 15 & Djibouti* & - & - & - \\
\hline 16 & Egypt & 4 & 1 & One individual in both Panels. \\
\hline 17 & Equatorial Guinea* & - & - & - \\
\hline 18 & Eritrea* & - & - & - \\
\hline 19 & Ethiopia* & - & - & - \\
\hline 20 & Gabon & 4 & 4 & - \\
\hline 21 & Gambia & 0 & 0 & Need to make appointments. \\
\hline 22 & Ghana & 4 & 3 & - \\
\hline 23 & Guinea & 2 & 2 & $\begin{array}{l}\text { The same individuals on both } \\
\text { Panels and all expired in } 1987 \text {. }\end{array}$ \\
\hline 24 & Guinea Bissau* & - & - & - \\
\hline 25 & Kenya & 4 & 4 & - \\
\hline 26 & Lesotho & 2 & 4 & $\begin{array}{l}\text { Two individuals on both Panels and } \\
\text { all expired in } 1989 .\end{array}$ \\
\hline 27 & Liberia & 4 & 2 & All expired in 1991. \\
\hline 28 & Libya* & - & - & - \\
\hline 29 & Madagascar & 3 & 3 & All expired in 1987. \\
\hline 30 & Malawi & 1 & 1 & $\begin{array}{l}\text { The same individual on both Panels } \\
\text { and expired in } 2012 \text {. }\end{array}$ \\
\hline 31 & Mali & 4 & 4 & $\begin{array}{l}\text { The same individuals on both } \\
\text { Panels. }\end{array}$ \\
\hline 32 & Mauritania & 1 & 1 & $\begin{array}{l}\text { The same individual on both } \\
\text { Panels. }\end{array}$ \\
\hline 33 & Mauritius & 4 & 4 & $\begin{array}{l}\text { The same individuals on both } \\
\text { Panels. }\end{array}$ \\
\hline 34 & Morocco & 4 & 4 & $\begin{array}{l}\text { The same individuals on both } \\
\text { Panels. }\end{array}$ \\
\hline 35 & Mozambique & 0 & 0 & Need to make appointments. \\
\hline 36 & Namibia* & - & - & - \\
\hline 37 & Niger & 4 & 4 & All expired in 1997. \\
\hline 38 & Nigeria & 4 & 4 & - \\
\hline 39 & Rwanda & 4 & 4 & - \\
\hline 40 & Sao Tome \& Principe & 0 & 0 & Need to make appointments. \\
\hline 41 & Senegal & 3 & 0 & All expired in 2004. \\
\hline 42 & Seychelles & 2 & 0 & I expired in May 2018. \\
\hline 43 & Sierra Leone & 4 & 4 & All expired in 1990. \\
\hline 44 & Somalia & 3 & 2 & Two individuals on both Panels. \\
\hline 45 & South Africa* & - & - & - \\
\hline 46 & South Sudan & 0 & 0 & Need to make appointments. \\
\hline 47 & Sudan & 0 & 0 & Need to make appointments. \\
\hline 48 & Swaziland (Eswatini) & 0 & 0 & Need to make appointments. \\
\hline 49 & Tanzania & 4 & 0 & All expired in 2005. \\
\hline 50 & Togo & 4 & 3 & Three individuals on both Panels. \\
\hline 51 & Tunisia & 4 & 4 & - \\
\hline
\end{tabular}




\begin{tabular}{|l|l|l|l|l|}
\hline 52 & Uganda & 2 & 4 & $\begin{array}{l}\text { Four conciliators expired in 1973; } \\
\text { one arbitrator 1979 \& another } \\
\text { arbitrator in 2016. }\end{array}$ \\
\hline 53 & Zambia & 0 & 0 & Need to make appointments. \\
\hline 54 & Zimbabwe & 4 & 4 & - \\
\hline
\end{tabular}

Source: https://icsid.worldbank.org/en/Pages/about/Database-of-Panel-Members.aspx\#a7 
Table 2: African States: Colonisation and Signing of ICSID

\begin{tabular}{|c|c|c|c|c|}
\hline No & African State & Colonising Country & $\begin{array}{l}\text { Date of } \\
\text { Independence }\end{array}$ & Date ICSID Signed \\
\hline 1 & Algeria & France & 5 July 1962 & Apr 17, 1995 \\
\hline 2 & Angola* & Portugal & 11 Nov 1975 & - \\
\hline 3 & Benin Republic & France & 1 Aug 1960 & Sep 10, 1965 \\
\hline 4 & Botswana & Britain & 30 Sep 1966 & Jan15. 1970 \\
\hline 5 & Burkina Faso & France & 5 Aug 1960 & Sep 16. 1965 \\
\hline 6 & Burundi & Belgium & $1 \mathrm{Jul} 1962$ & Feb 17, 1967 \\
\hline 7 & Cabo Verde & Portugal & $5 \mathrm{Jul} 1975$ & Dec 20, 2010 \\
\hline 8 & Cameroon & France, UK & 1 Jan 1960 & Sep 23, 1965 \\
\hline 9 & $\begin{array}{ll}\text { Central } & \text { Africa } \\
\text { Republic } & \\
\end{array}$ & France & 13 Aug 1960 & Aug 26, 1965 \\
\hline 10 & Chad & France & 11 Aug 1960 & May 12,1966 \\
\hline 11 & Comoros & France & 6 Jul 1975 & Sep 26, 1978 \\
\hline 12 & Congo Republic & France & 15 Aug 1960 & $\operatorname{Dec} 27,1965$ \\
\hline 13 & $\begin{array}{l}\text { Democratic } \\
\text { Republic of Congo }\end{array}$ & Belgium & 30 Jun 1960 & Oct 29,1968 \\
\hline 14 & Cote d'Ivoire & France & 7 Aug 1960 & Jun 30, 1965 \\
\hline 15 & Djibouti* & France & 27 Jun 1977 & - \\
\hline 16 & Egypt & Britain & 22 Feb 1922 & Feb 11, 1972 \\
\hline 17 & Equatorial Guinea* & Spain & 12 Oct 1968 & - \\
\hline 18 & Eritrea* & - & 24 May 1993 & - \\
\hline 19 & Ethiopia* & - & - & Sep 21, 1965 \\
\hline 20 & Gabon & France & 17 Aug 1960 & Sep 21, 1965 \\
\hline 21 & Gambia & Britain & 18 Feb 1965 & Oct 01,1974 \\
\hline 22 & Ghana & Britain & 6 Mar 1957 & Nov 26, 1965 \\
\hline 23 & Guinea & France & 2 Oct 1958 & Aug 27, 1968 \\
\hline 24 & Guinea Bissau* & Portugal & 24 Sep 1973 & Sep 04, 1991 \\
\hline 25 & Kenya & Britain & 12 Dec 1963 & May 24, 1966 \\
\hline 26 & Lesotho & Britain & 4 Oct 1966 & Sep 19, 1968 \\
\hline 27 & Liberia & $\begin{array}{l}\text { American } \\
\text { colonization society }\end{array}$ & $26 \mathrm{Jul} 1847$ & - \\
\hline 28 & Libya* & Italy & 24 Dec 1951 & - \\
\hline 29 & Madagascar & France & 26 Jun 1960 & Jun 01, 1966 \\
\hline 30 & Malawi & Britain & 6 Jul 1964 & Jun 09, 1966 \\
\hline 31 & Mali & France & 22 Sep 1960 & Apr 09, 1976 \\
\hline 32 & Mauritania & France & 28 Nov 1960 & Jul 30, 1965 \\
\hline 33 & Mauritius & Britain & 12 Mar 1968 & Jun 02, 1969 \\
\hline 34 & Morocco & France, Spain & 2 Mar 1956 & Oct 11,1965 \\
\hline 35 & Mozambique & \begin{tabular}{|l|} 
Portugal \\
\end{tabular} & 25 Jun 1975 & Apr 04, 1995 \\
\hline 36 & Namibia* & $\begin{array}{l}\text { South African } \\
\text { mandate }\end{array}$ & 21 Mar 1990 & Oct 26,1998 \\
\hline 37 & Niger & France & 3 August 1960 & Aug 23, 1965 \\
\hline 38 & Nigeria & Britain & 1 October 1960 & Jul 13, 1965 \\
\hline 39 & Rwanda & $\begin{array}{l}\text { Belgium } \\
\text { administered UN } \\
\text { trusteeship }\end{array}$ & 1 Jul 1962 & Apr 21, 1978 \\
\hline 40 & Sao Tome \& Principe & Portugal & 12 July 1975 & Oct 01, 1999 \\
\hline 41 & Senegal & France & 4 April 1960 & Sep 26, 1966 \\
\hline 42 & Seychelles & Britain & 29 Jun 1976 & Feb 16, 1978 \\
\hline 43 & Sierra Leone & Britain & 27 April 1961 & Sep 27, 1965 \\
\hline 44 & Somalia & $\begin{array}{l}\text { British Somaliland } \\
\text { Italian Somaliland }\end{array}$ & 1 Jul 1960 & Sep 27, 1965 \\
\hline
\end{tabular}




\begin{tabular}{|l|l|l|l|l|}
\hline 45 & South Africa* & Britain & 31 May 1961 & - \\
\hline 46 & South Sudan & - & 9 Jul 2011 & Apr 18, 2012 \\
\hline 47 & Sudan & Egypt, Britain & 1 Jan 1956 & Mar 15, 1967 \\
\hline 48 & Swaziland (Eswatini) & Britain & 6 Sep 1968 & Nov 03, 1970 \\
\hline 49 & Tanzania & Britain & 26 Apr 1964 & Jan 10, 1992 \\
\hline 50 & Togo & $\begin{array}{l}\text { France- } \\
\text { administered UN } \\
\text { trusteeship }\end{array}$ & 27 April 1960 & Jan 24, 1966 \\
\hline 51 & Tunisia & France & 20 Mar 1956 & May 05, 1965 \\
\hline 52 & Uganda & Britain & 9 Oct 1962 & Jun 07, 1966 \\
\hline 53 & Zambia & Britain & 24 Oct 1964 & Jun 17, 1970 \\
\hline 54 & Zimbabwe & Britain & 18 Apr 1980 & Mar 25, 1991 \\
\hline
\end{tabular}

Sources: ICSID website and http://www.japanafricanet.com/directory/presidents/africanindependence.html

*: Non-ICSID member state 
Table 3: African Member States and Designated Courts for ICSID Awards

\begin{tabular}{|c|c|c|}
\hline No & African State & Designated Court for ICSID Awards \\
\hline 1 & Algeria & None \\
\hline 2 & Benin Republic & Cour Suprême \\
\hline 3 & Botswana & Registrar of the High Court \\
\hline 4 & Burkina Faso & Cour Suprême \\
\hline 5 & Burundi & Tribunal de Première Instance de Bujumbura \\
\hline 6 & Cabo Verde & None \\
\hline 7 & Cameroon & Cour Suprême (Chambre Administrative) \\
\hline 8 & $\begin{array}{ll}\text { Central Africa } \\
\text { Republic }\end{array}$ & Le Tribunal de Grande Instance \\
\hline 9 & Chad & None \\
\hline 10 & Comoros & None \\
\hline 11 & Congo Republic & Tribunal de Grande Instance de Brazzaville \\
\hline 12 & $\begin{array}{l}\text { Democratic } \\
\text { Republic of Congo }\end{array}$ & None \\
\hline 13 & Cote d'Ivoire & Président du Tribunal de Première Instance d'Abidjan \\
\hline 14 & Egypt & Ministry of Justice \\
\hline 15 & Gabon & None \\
\hline 16 & Gambia & None \\
\hline 17 & Ghana & High Court \\
\hline 18 & Guinea & Procureur Général \\
\hline 19 & Kenya & High Court \\
\hline 20 & Lesotho & Permanent Secretary for Foreign Affairs \\
\hline 21 & Liberia & Supreme Court \\
\hline 22 & Madagascar & Chambre Administrative de la Cour Suprême \\
\hline 23 & Malawi & High Court \\
\hline 24 & Mali & None \\
\hline 25 & Mauritania & Supreme Court of Mauritania (Nouakchott) \\
\hline 26 & Mauritius & Supreme Court \\
\hline 27 & Morocco & $\begin{array}{l}\text { "Président du Tribunal Régional" of the district where the } \\
\text { enforcement is to take place }\end{array}$ \\
\hline 28 & Mozambique & None \\
\hline 29 & Niger & $\begin{array}{l}\text { Tribunal de Première Instance dans le ressort duquel la } \\
\text { sentence arbitral doit être exécutée }\end{array}$ \\
\hline 30 & Nigeria & Supreme Court \\
\hline 31 & Rwanda & Tribunal de Première Instance de Kigali \\
\hline 32 & Sao Tome \& Principe & None \\
\hline 33 & Senegal & Cour d'Appel de Dakar \\
\hline 34 & Seychelles & None \\
\hline 35 & Sierra Leone & Cabinet through the Ministry of Finance \\
\hline 36 & Somalia & None \\
\hline 37 & South Sudan & None \\
\hline 38 & Sudan & Khartoum Province Court \\
\hline 39 & Swaziland (Eswatini) & High Court \\
\hline 40 & Tanzania & None \\
\hline 41 & Togo & $\begin{array}{l}\text { Président du Tribunal de Droit Moderne de Première } \\
\text { Instance de Lomé }\end{array}$ \\
\hline 42 & Tunisia & $\begin{array}{l}\text { "Tribunal de Première Instance" having jurisdiction in the } \\
\text { place where the enforcement is to take place }\end{array}$ \\
\hline 43 & Uganda & None \\
\hline 44 & Zambia & High Court \\
\hline 45 & Zimbabwe & High Court \\
\hline
\end{tabular}


